\title{
DE
}

DE GRUYTER

OPEN

Arch. Min. Sci., Vol. 61 (2016), No 4, p. 967-977

Electronic version (in color) of this paper is available: http://mining.archives.pl

DOI 10.1515/amsc-2016-0064

RYSZARD SNOPKOWSKI*, ANETA NAPIERAJ*, MARTA SUKIENNIK*

\section{METHOD OF THE ASSESSMENT OF THE INFLUENCE OF LONGWALL EFFECTIVE WORKING TIME ONTO OBTAINED MINING OUTPUT}

\section{METODA OCENY WPLYWU EFEKTYWNEGO CZASU PRACY W ŚCIANIE NA UZYSKIWANE WYDOBYCIE}

Method of the influence of assessment of longwall effective working time onto obtained mining output, has been discussed in the present study.

Mean flow rate of the winning stream being also considered as directional factor of linear function describing relation between daily output and effective mining in the longwall face, has been determined.

Such relation - presented also graphically in form of the diagram - determines significance and influence of the effective working time onto obtained mining output. This relation should be considered as motivation in particular for supervisory personnel, as it shows advantages resulting from elongation of this time, as well as it shows possible loses of the daily output in a case, when the effective working time in given longwall face was shortened.

Keywords: longwall faces, production process, daily output, effective working time, effectiveness of production process

Treścią pracy jest metoda oceny wpływu efektywnego czasu pracy w ścianie na uzyskiwane wydobycie.

Wyznaczane jest średnie natężenie strugi urobku, będące jednocześnie współczynnikiem kierunkowym funkcji liniowej, opisującej zależność wydobycia zmianowego od efektywnego czasu pracy w przodku.

W ten sposób wyznaczona zależność - prezentowana także graficznie w formie wykresu - zwraca uwagę na znaczenie i wpływ efektywnego czasu pracy na uzyskiwane wydobycie. Powinna działać motywacyjnie (w szczególności chodzi o pracowników dozoru ruchu), gdyż pokazuje korzyści wynikające ze zwiększenia długości tego czasu, ale także pokazuje możliwości strat w wydobyciu zmianowym, jeśliby efektywny czas pracy w danym przodku ścianowym uległ skróceniu.

Słowa kluczowe: przodki ścianowe, proces produkcyjny, wydobycie zmianowe, efektywny czas pracy, efektywność procesu produkcyjnego

* AGH UNIVERSITY OF SCIENCE AND TECHNOLOGY, FACULTY OF MINING AND GEOENGINEERING, AL. A. MICKIEWICZA 30, 30-059 KRAKÓW, POLAND 


\section{Introduction}

In Polish hard coal mines mining works are conducted in longwall faces equipped with longwall systems. i.e. sets of machines suitably selected with respect to mining efficiency and their mutual coworking. Technical parameters of the longwall system are so high that they don't disturb obtaining high working efficiency. i.e. higher production efficiency in longwalls (Snopkowski \& Sukiennik, 2012).

So, what in actual conditions particularly strong influences the mining output being a barrier of its increase?

So called effective working time $\left(T_{e}\right)$ gives answer to this question. It is time in which production process can be realized, i.e. time spent by the personnel in the longwall face, minus time lost in result of brake-downs and working breaks independent on technology used In the longwall face.

Thus length of the effective working time is influenced by the time of break-downs and working breaks not resulting from the technology used and length of time spent by the personnel in the longwall face, what is dependent on the distance between the longwall face and personnel pit shaft (Snopkowski \& Sukiennik, 2013).

Finally we can assume that increase of the effective working time causes growth of the obtained winning output in conditions occurring in every longwall face.

However it is practical question: ,what mining output growth could be expected if effective time of the longwall face workings was elongated?"

In order to answer this question daily longwall output in function of effective working time for given conditions and technology used should be determined. Elaboration and use of such characteristics in practice could be motivational for personnel paying attention to the meaning and influence of effective working time onto obtained output. So such characteristics should be in disposal of supervisory personnel of each longwall.

Based on the above premises, method of the assessment of the longwall effective workings onto received mining output for various mining technologies, has been developed and described in next chapters of the present study.

Procedural scheme of the proposed method is shown in Fig. 1.

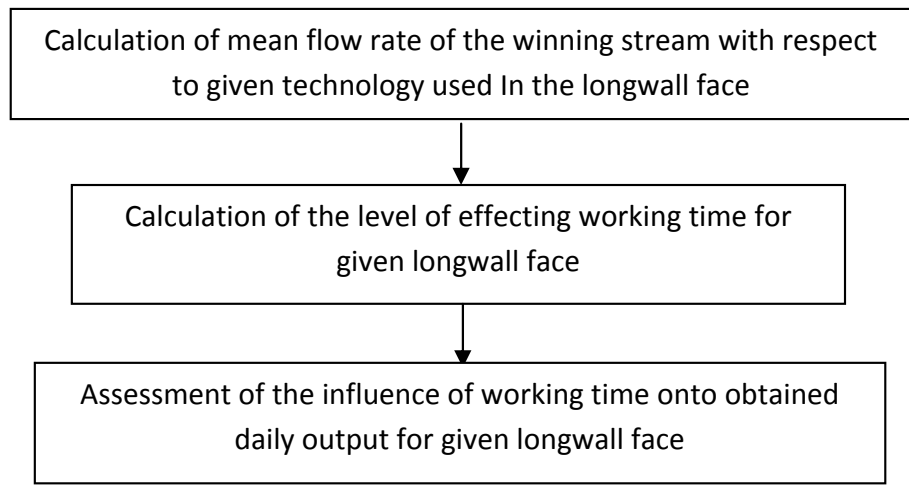

Fig. 1. Algorithm of the method of assessment of the working time influence onto daily mining output for given longwall face (Elaborated by the authors of the present study) 


\section{Mean flow rate of the winning stream for various longwall shearer-based mining technologies}

For each technology applied in the longwall face we can determine mean flow rate of the winning stream obtained during production cycle, which is dependent on mining output from this cycle, cycle duration and mode of the shearer cutting.

Procedure of calculation of the mean flow rate of winning stream for technologies commonly used in longwall faces is described in the present study. It should be noted that only these technologies are applied, so far. Quite frequent are solutions in which, for example, place of the shearer slotting is different than at the end of the longwall. However, it should be underlined that presented detailed analysis of the production cycle can also be used in such cases (Snopkowski, 2000).

Value of the mean flow rate of the winning stream is used in further calculations of the influence of effective longwall working time onto obtained mining output.

\section{Method of calculation of $\varphi_{1 k}-$ mean flow rate of winning stream in technology of shearer-based unidirectional mining}

Scheme of the production cycle executed in technology of shearer-based unidirectional mining is shown in Fig. 2. Vertical axis reflects longwall length, whereas horizontal axis is scaled in time units. Shearer slotting is made at the end of the longwall in manner shown in the scheme.

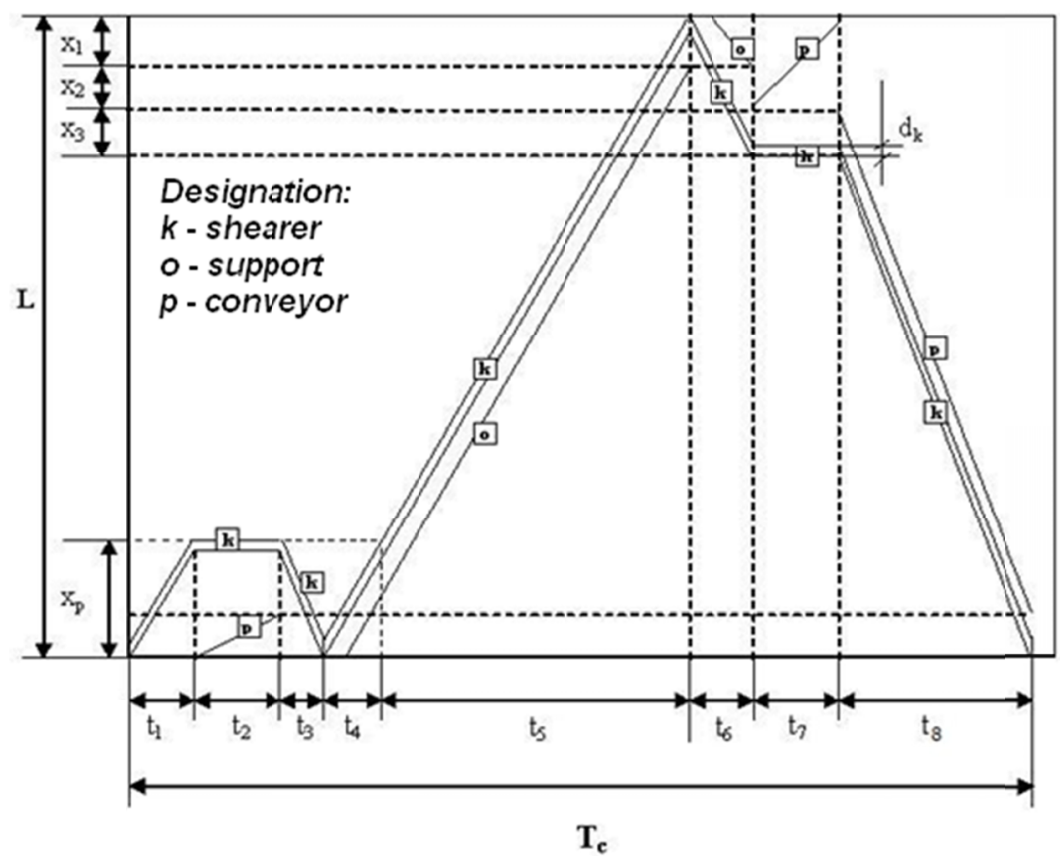

Fig. 2. Scheme of the production cycle for technology of unidirectional shearer mining (Snopkowski \& Napieraj, 2012) 
The scheme in question comprises all activities and works needed for coal mining execution on the total longwall length at the depth of single web, drive units of the longwall conveyor work in vertical system (no niches are made).

The following markings are present on the diagram:

$L$ - longwall length [m],

$T_{c}$ - duration of production cycle [min],

$t_{1}, t_{2}, \ldots, t_{8}-$ times of execution of individual phases of the production cycle [min],

$d_{k}$ - shearer length $[\mathrm{m}]$,

$x_{1}, x_{2}, x_{3}-$ mutual distances of executed activities and workings in scope of the system shearer - support - conveyor [m],

$x_{p}$ - distance between shearer stoppage place and longwall-roadway crossing [m].

Duration of the production cycle is a sum of realization times of its phases (Snopkowski \& Napieraj, 2012), so:

$$
T_{c}=t_{1}+t_{2}+t_{3}+t_{4}+t_{5}+t_{6}+t_{7}+t_{8}
$$

where:

$$
t_{1}=\frac{1}{V_{z}} \cdot\left(x_{p}-d_{k}\right)
$$

$V_{z}$ - advance rate of slotted shearer [m/min].

Time $t_{2}$ is a time of the drive unit relocation, beginning from the moment of pillars descending up to the moment of their expanding, after shift of full web.

$$
t_{3}=\frac{1}{V_{r}} \cdot\left(x_{p}-d_{k}\right)
$$

$V_{r}-$ shearer working advance rate $[\mathrm{m} / \mathrm{min}]$.

$$
t_{4}=\frac{1}{V_{c z}} \cdot\left(x_{p}-d_{k}\right)
$$

$V_{c z}$ - shearer advance rate (shearer advance rate during shearer track cleaning) $[\mathrm{m} / \mathrm{min}]$

$$
\begin{gathered}
t_{5}=\frac{1}{V_{r}} \cdot\left(L-x_{p}-d_{k}\right) \\
t_{6}=\frac{1}{V_{c z}} \cdot\left(x_{1}+x_{2}+x_{3}-d_{k}\right)
\end{gathered}
$$

$x_{1}=d_{k}+s[\mathrm{~m}]$, where $s-$ distance between portable support and shearer [m],

$x_{2}$ - distance between portable conveyor and support [m],

$x_{3}=d_{k}+p[\mathrm{~m}]$, where $p-$ minima distance between portable conveyor and shearer [m].

Time $t_{7}$ is a time of turning station relocation - determined analogically as in case of time $t_{2}$.

$$
t_{8}=\frac{1}{V_{c z}} \cdot\left(L-x_{1}-x_{2}-x_{3}\right)
$$


Thus duration of the production cycle for technology of shearer-based mining presented in scheme 2 (after substitution into formula 1) has following form:

$$
T_{c}=\left(\frac{1}{V_{z}}+\frac{1}{V_{r}}+\frac{1}{V_{c z}}\right)\left(x_{p}-d_{k}\right)+\frac{1}{V_{r}}\left(L-x_{p}-d_{k}\right)+\frac{1}{V_{c z}}\left(L-d_{k}\right)+t_{2}+t_{7}
$$

Mean flow rate of the winning stream in production cycle, executed in technology of unidirectional shearer-based technology $\varphi_{1 k}$ is determined by formula:

$$
\varphi_{1 k}=\frac{W_{c}}{T_{c}}
$$

$\varphi_{1 k}$ - mean flow rate of the winning stream in technology of unidirectional shearer-based technology $[\mathrm{Mg} / \mathrm{min}]$

$W_{c}$ - output from production cycle $[\mathrm{Mg} / \mathrm{cycle}]$

$$
W_{c}=H \cdot z \cdot L \cdot \gamma \cdot \rho
$$

where:

$$
\begin{aligned}
H & - \text { longwall height }[\mathrm{m}], \\
z & - \text { shearer web }[\mathrm{m}], \\
L & - \text { longwall length }[\mathrm{m}], \\
\gamma & - \text { coal bulk density }\left[\mathrm{Mg} / \mathrm{m}^{3}\right], \\
\rho & - \text { web factor }[-] .
\end{aligned}
$$

After substitution into formula (9), mean flow rate of the winning stream in technology of unidirectional shearer-based technology $\varphi_{1 k}$ is calculated from formula:

$$
\varphi_{1 k}=\frac{H \cdot z \cdot L \cdot \gamma \cdot \rho}{\left(\frac{1}{V_{z}}+\frac{1}{V_{r}}+\frac{1}{V_{c z}}\right)\left(x_{p}-d_{k}\right)+\frac{1}{V_{r}}\left(L-x_{p}-d_{k}\right)+\frac{1}{V_{c z}}\left(L-d_{k}\right)+t_{2}+t_{7}}
$$

\section{Calculation procedure $\varphi_{2 k}$ - mean flow rate of the winning stream in technology of two-directional shearer-based mining}

Scheme of the production cycle executed in technology of two-directional shearer-based mining is shown in Fig. 3. Longwall length is marked on vertical axis and horizontal axis is scaled in time units. Shearer-based mining is realized with full longwall height in both directions. Shearer slotting takes place at the longwall end in manner shown in the diagram.

The scheme in question comprises all activities and workings needed for the coal mining on whole longwall length with single web cutting depth, including longwall conveyor drive units, which are operated in perpendicular system (no niches are made).

In the Fig. 3 used following designations:

$L$ - longwall length [m],

$T_{c}$ - duration of the production cycle [min],

$t_{1}, t_{2}, \ldots, t_{6}$ - times of execution of individual phases of production cycle [min],

$d_{k}$ - shearer length $[\mathrm{m}]$, 
972

$\begin{aligned} x_{1}, x_{2}, x_{3}- & \text { mutual distances of executed activities and workings in scope of the system } \\ & \text { shearer }- \text { support }- \text { conveyor [m], } \\ x_{p}- & \text { distance between place of shearer standstill and longwall-roadway crossing [m]. }\end{aligned}$

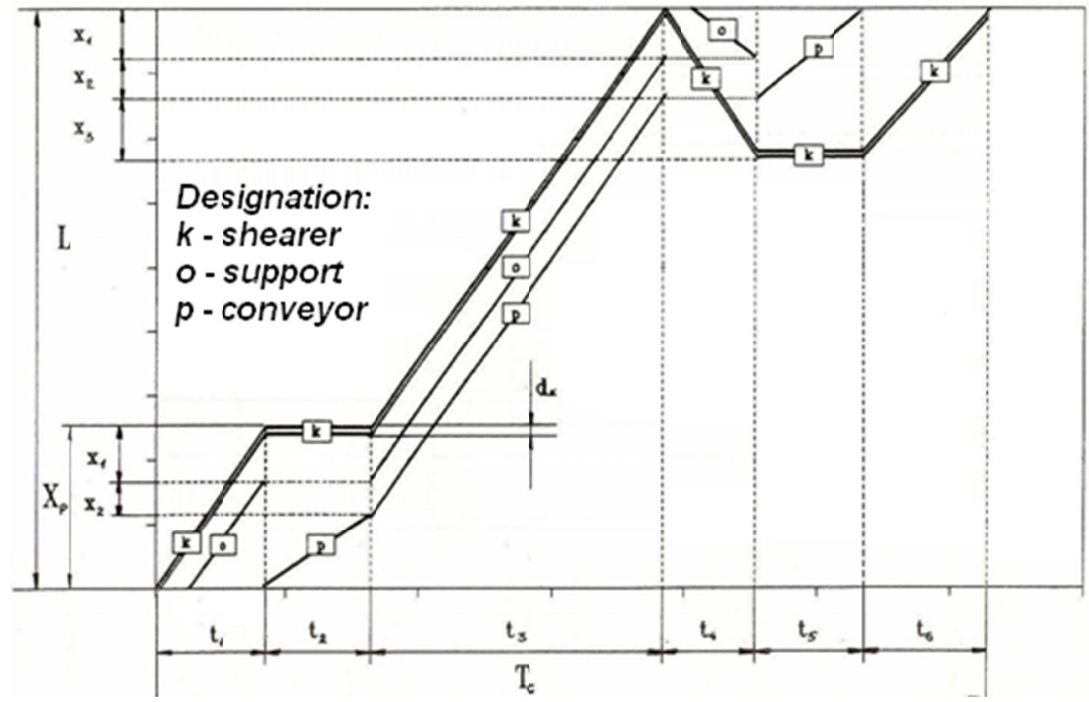

Fig. 3. Scheme of the production cycle executed in technology of two-directional shearer-based mining (Snopkowski R., Napieraj A., 2012)

Duration of the production cycle (executed in technology presented in Fig. 3) is a sum of times of realization of individual cycle phases, thus

$$
T_{c}=t_{1}+t_{2}+t_{3}+t_{4}+t_{5}+t_{6}
$$

where:

$$
t_{1}=\frac{1}{V_{c z}} \cdot\left(x_{p}-d_{k}\right)
$$

$V_{c z}$ - shearer advance rate $[\mathrm{m} / \mathrm{min}]$.

Time $t_{2}$ is a time of the drive unit relocation, beginning from the moment of descending of pillars, up to the moment of their expansion after shifting with full web.

$$
t_{3}=\frac{1}{V_{r}} \cdot\left(L-x_{p}\right)
$$

$V_{r}$ — shearer working velocity [ $\left.\mathrm{m} / \mathrm{min}\right]$.

$$
t_{4}=\frac{1}{V_{z}} \cdot\left(x_{1}+x_{2}+x_{3}-d_{k}\right)
$$


$V_{z}$ - prędkość kombajnu w trakcie zawrębiania [m/min],

$x_{1}=d_{k}+s[\mathrm{~m}]$,

$s$ - distance between relocated support and shearer [m],

$x_{2}$ - distance between relocated conveyor and support [m],

$x_{3}=d_{k}+p[\mathrm{~m}]$,

$p-$ minimal distance between relocated conveyor and shearer $[\mathrm{m}]$.

Time $t_{5}$ is a time of turning station relocation, beginning from the moment of descending of pillars, up to the moment of their expansion after shifting with full web.

$$
t_{6}=\frac{1}{V_{r}} \cdot\left(x_{1}+x_{2}+x_{3}-d_{k}\right)
$$

Duration of production cycle executed in technology of shearer-based two-directional mining (after substitution to formula 12), thus:

$$
T_{c}=\frac{1}{V_{c z}}\left(x_{p}-d_{k}\right)+\frac{1}{V_{r}} \cdot\left(L-x_{p}\right)+\left(\frac{1}{V_{z}}+\frac{1}{V_{r}}\right) \cdot\left(x_{2}+d_{k}+p+s\right)+t_{2}+t_{5}
$$

Mean flow rate of the winning stream obtained in technology of shearer-based two-directional mining $\varphi_{2 k}$ (Snopkowski, 2005), (Snopkowski, 2009) is calculated from formula:

$$
\varphi_{2 k}=\frac{W_{c}}{T_{c}}
$$

$\varphi_{2 k}-$ mean flow rate of the winning stream in technology of shearer-based two-directional mining $[\mathrm{Mg} / \mathrm{min}]$

$W_{c}$ - production cycle output $[\mathrm{Mg} / \mathrm{cycle}]$

$$
W_{c}=H \cdot z \cdot L \cdot \gamma \cdot \rho
$$

where:

$$
\begin{aligned}
& H-\text { longwall height }[\mathrm{m}], \\
& z-\text { shearer web }[\mathrm{m}], \\
& L-\text { longwall length }[\mathrm{m}], \\
& \gamma-\text { coal bulk density }\left[\mathrm{Mg} / \mathrm{m}^{3}\right], \\
& \rho-\text { web factor }[-] .
\end{aligned}
$$

After substitutions:

$$
\varphi_{2 k}=\frac{H \cdot z \cdot L \cdot \gamma \cdot \rho}{\frac{1}{V_{c z}}\left(x_{p}-d_{k}\right)+\frac{1}{V_{r}} \cdot\left(L-x_{p}\right)+\left(\frac{1}{V_{z}}+\frac{1}{V_{r}}\right) \cdot\left(x_{2}+d_{k}+p+s\right)+t_{2}+t_{5}}
$$




\section{Assessment of the influence of the longwall effective working time onto obtained mining output}

Output obtained during production shift can be calculated from the following formulas.

For shearer-based unidirectional mining technology:

$$
W_{z m}=T_{e} \cdot \varphi_{1 k}
$$

For shearer-based two-directional mining technology:

$$
W_{z m}=T_{e} \cdot \varphi_{2 k}
$$

where:

$W_{z m}$ - daily/per shift output $[\mathrm{Mg} / \mathrm{shift}]$,

$T_{e}$ - effective working time for single shift [min/shift], $\varphi_{1 k}, \varphi_{2 k}$ - mean flow rate of the winning stream (according to formula 11 or 20) [Mg/min].

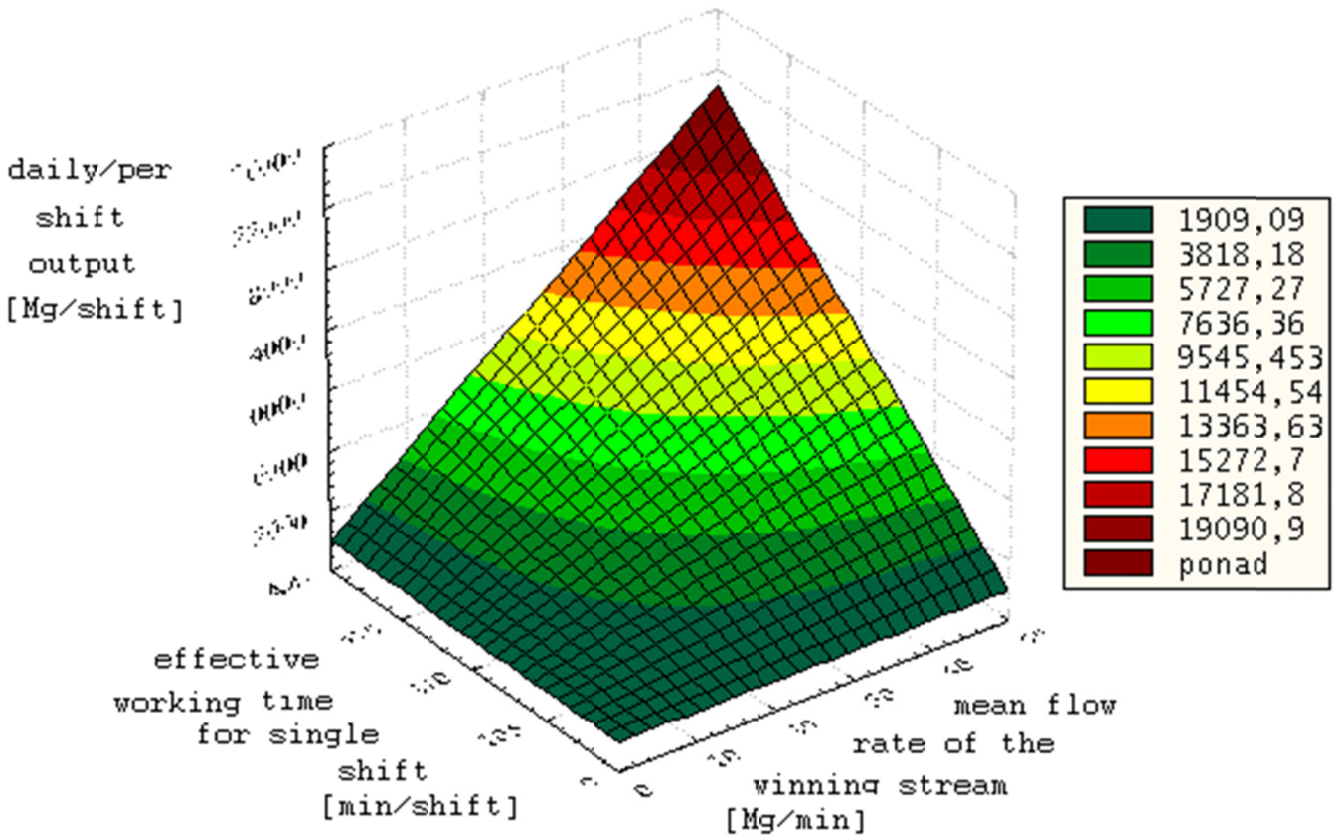

Fig. 4. Daily mining output in function of mean flow rate of the winning stream and effective working time (Elaborated by the author of the present study)

Diagram reflecting dependence of the daily output $(z)$ on mean flow rate of the winning stream $(y)$ and effective working time $(x)$ is shown in Fig. 4. Maximal values were assumed at the level of theoretical transport efficiency of longwall conveyor $(y)$, assuming also effective working time $(x)$ as $420 \mathrm{~min}$. 
In practice, obtained values have considerably lower level, however, mentioned diagram allows assessment of the of generated in the longwall face mean flow rate of the winning stream and effective working time onto obtained output, within broad scope of values (Snopkowski, 2002).

Concrete step in developed method (according to Fig. 1) comprises assessment of effective (real) working time for conditions occurring in given longwall face. Data needed for assessment of this time should be taken from shift reports and opinion of supervisory personnel. Such determined effective (real) working time is marked with $T_{e}^{r}$.

Using determined for conditions occurring in given longwall face values of mean flow rate of winning stream (according to formula 11 or 20) and effective working time $T_{e}^{r}$ level of the daily output $W_{z m}^{r}$ is calculated:

$$
W_{z m}^{r}=T_{e}^{r *} \varphi_{1 k}
$$

for unidirectional mining, or

$$
W_{z m}^{r}=T_{e}^{r *} \varphi_{2 k}
$$

for two-directional mining.

Thus parameter $W_{z m}^{r}$ can be considered as the mining output level, which during single working shift can be obtained from the longwall face at remaining constant (actual, real) length of the effective working time $T_{e}^{r}$.

In order to determine advantages or eventual loses in obtained output, diagram of daily output in function of effective working time should be developed. Level of actual daily output $W_{z m}^{r}$, obtained for actual effective working time $T_{e}^{r}$ is plotted on the diagram in question. Areas of so called potential output are marked on the diagram. Potential output is defined as such output level, which could be obtained in the longwall face, if length of the effective working time exceeded actual value or was even shorter.

Procedure of the diagram creation is shown in calculation example illustrating developed methodology, what is described in sub-chapter 3.1 of the present study.

\subsection{Example of the assessment of effective working time influence onto obtained mining output}

Data used in this example are related with fully mechanized longwall face, in which technology of two-directional mining technology was applied. For conditions occurring in this longwall face, mean flow rate of the winning stream was calculated according to the formula (20):

$$
\varphi_{2 k}=\frac{H \cdot z \cdot L \cdot \gamma \cdot \rho}{\frac{1}{V_{c z}}\left(x_{p}-d_{k}\right)+\frac{1}{V_{r}} \cdot\left(L-x_{p}\right)+\left(\frac{1}{V_{z}}+\frac{1}{V_{r}}\right) \cdot\left(x_{2}+d_{k}+p+s\right)+t_{2}+t_{5}}
$$

Data used in this formula possessed the following values: longwall height $(H)-3,4[\mathrm{~m}]$, shearer web $(z)-0,6[\mathrm{~m}]$, longwall length $(L)-260[\mathrm{~m}]$, coal bulk density $(\gamma)-1,3[\mathrm{Mg} / \mathrm{m} 3]$, web factor $(\rho)-1,0[-]$, maneuver shearer advance rate $\left(V_{c z}\right)-24[\mathrm{~m} / \mathrm{min}]$, distance between shearer stoppage place and longwall - roadway crossing $\left(x_{p}\right)-25[\mathrm{~m}]$, shearer length $\left(d_{k}\right)-12[\mathrm{~m}]$, working shearer advance rate $\left(V_{r}\right)-10[\mathrm{~m} / \mathrm{min}]$, shearer advance rate during slotting $\left(V_{z}\right)-7[\mathrm{~m} / \mathrm{min}]$, 
distance between relocated conveyor and support $\left(x_{2}\right)-10[\mathrm{~m}]$, minimal distance between relocated conveyor and shearer $(p)-10[\mathrm{~m}]$, distance between relocated support and shearer $(s)-9[\mathrm{~m}]$, drive unit relocation time $\left(t_{2}\right)-18$ [min], turning station relocation time $\left(t_{5}\right)-15$ [min].

After suitable substitutions to formula (20) were made, mean flow rate of the winning stream in tested longwall face amounted for $\varphi_{2 k}=10,29[\mathrm{Mg} / \mathrm{min}]$.

Effective working time determined on the basis of shift reports and assessment of the supervisory personnel in tested longwall face was kept at the level $T_{e}^{r}=220$ [min/shift].

Real daily (shift) output for this longwall face - obtained in time calculated according to formula (24), amounts for $W_{z m}^{r}=2263,8$ [Mg/shift].

Obtained daily output in function of effective working time determined for conditions occurring in tested longwall face is shown in Fig. 5. It is linear relation and its directional factor amounts for 10,29. Directional factor is then equal to mean flow rate of the winning stream in tested longwall face. The bigger value of directional factor the bigger is influence of effective working time onto obtained output (even small change of the length of effective working time in the longwall face causes big changes of obtained output).

Values of the effective working time exceeding actual level $T_{e}^{r}$ is marked with green color (on axis $x$ ). Increase of the time $T_{e}^{r}$ in this longwall face (if possible) could be reflected by daily output increase, what was marked also with green color on axis $y$ (potential output - increase).

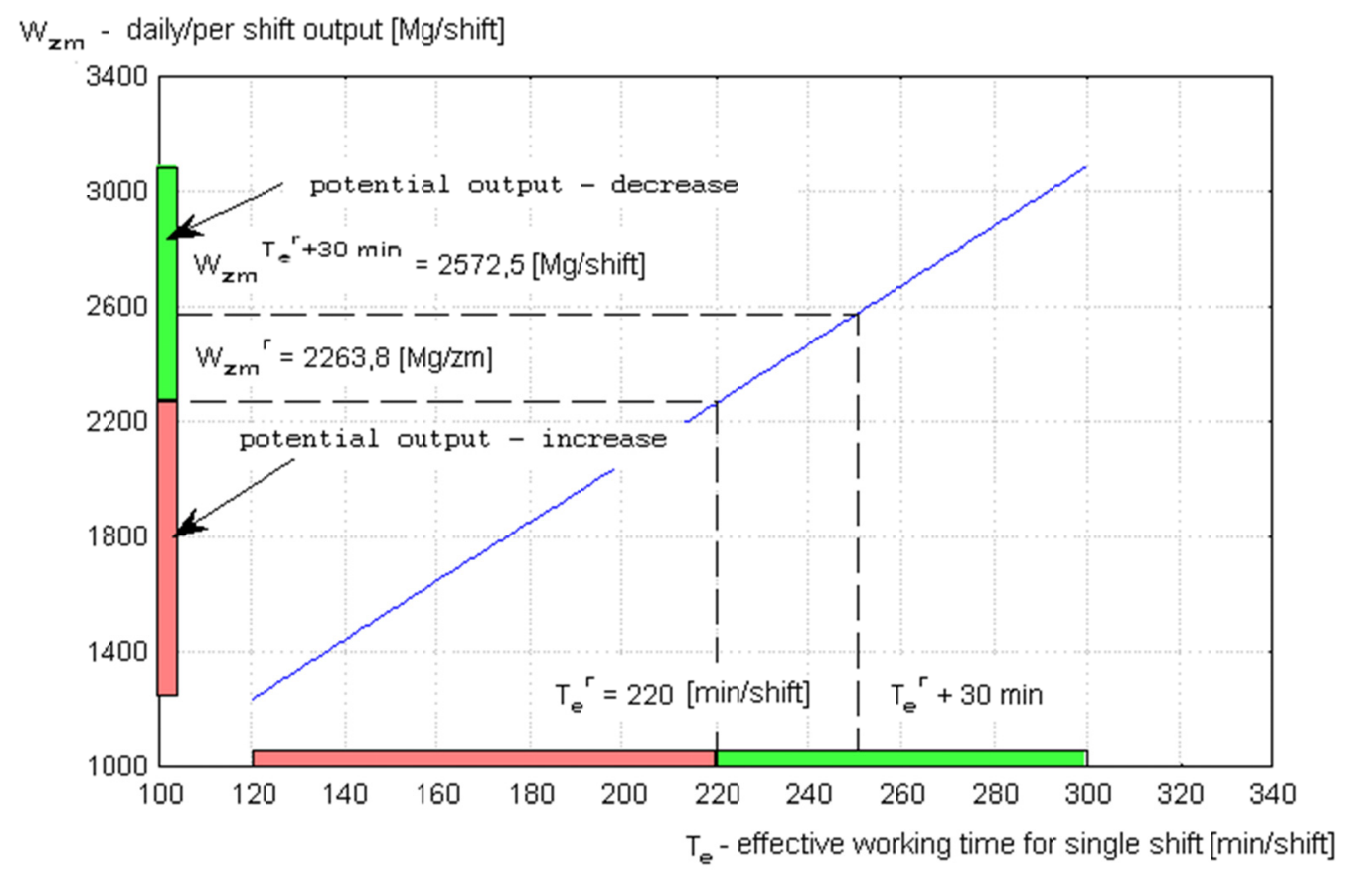

Fig. 5. Daily output in function of effective working time for conditions occurring in longwall face, in which mean flow rate of the winning stream amounts for $10,29[\mathrm{Mg} / \mathrm{min}]$.

(Elaborated by the author of the present study) 
Mining output drop from this longwall face is marked with red color if effective working time occurring actually in the longwall face was reduced. It is obviously non profitable situation, what is marked with red color at the diagram.

Results of elongation of the time $T_{e}^{r}$ of with 30 minutes is a good example illustrating positive results of elongation of effective working time in this longwall face. Suitable calculations proved that elongation of effective working time with 30 minutes could result in the increase of the daily output up to the level of 2572,5 [Mg/shift], what is also marked In the diagram.

\section{Final conclusions}

Effective working time in the longwall face is one of the factors deciding about longwall production level. This key problem comprises undertaking activities making this time possibly long during each production shift. This activities are controlled by the mining plant supervisory personnel and they comprise: shortening of the walking (driving) time to the longwall, division of work activities, shortening of brake downs time and working brakes independent on the used technology, etc.

The method presented in this study can be very useful tool for assessment of the effective working time in longwall face and its influence on obtained output.

The developed method allows - for conditions occurring in given longwall face - calculation of so called mean flow rate of the winning stream being also a directional factor of linear function describing dependence of daily output on effective working time in the longwall face.

Such formulated relation - presented also in form of the diagram - pay our attention to meaning and influence of effective working time onto obtained mining output. It should motivate particularly supervisory personnel because it brings evident advantages resulting from elongation of this time, and it also shows possible losses in daily output, in case when effective working time was shortened in given longwall face.

\section{References}

Snopkowski R., 2000. Boundary conditions for elementary functions of probability densities for the production process realized in longwalls. Arch. Min. Sci., Vol. 45, No 4, p. 501-510.

Snopkowski R., 2002. Longwall output plan considered in probability aspect. Arch. Min. Sci., Vol. 47, No 3, p. 413-420.

Snopkowski R., 2005. The use of the Stochastic Simulation for Identyfication of the Function of Output Probability Density. Arch. Min. Sci., Vol.50, No 4, p. 497-504.

Snopkowski R., 2009. Stochastic model of the longwall face excavation using two-way shearer mining technology. Arch. Min. Sci., Vol. 54, No 3, p. 573-585.

Snopkowski R., Napieraj A., 2012. Method of the production cycle duration time modeling within hard coal longwall faces. Arch. Min. Sci., Vol. 57, No 3, p. 573-585.

Snopkowski R., Sukiennik M., 2012. Selection of the longwall face crew with respect to stochastic character of the production process - part 1 - procedural description. Arch. Min. Sci., Vol. 57, No 4, p. 1071-1088.

Snopkowski R., Sukiennik M., 2013. Longwall face crew selection with respect to stochastic character of the production process - part 2 - calculation example. Arch. Min. Sci., Vol. 58, No 1, p. 227-240. 